\title{
Pengembangan media video pembelajaran speaking berbasis Bahasa Ibu (Bahasa Sasak) di SMK Qamamrul Huda
}

\author{
${ }^{1}$ Ahmad Syukron Sidik, ${ }^{2}$ Farizan Fahmi \\ ${ }^{12}$ Pendidikan Bahasa Inggris, Fakultas Keguruan dan Ilmu Pendidikan, Universitas Qamarul Huda \\ Badaruddin \\ Email: Syukron47@gmail.com ${ }^{1}$, farizanfahmi458@gmail.com²
}

\begin{abstract}
Based on a preliminary study at SMK Qamarul Huda Bagu class X, various problems were found, both from low grades, a less interactive learning process and the media used in English subjects, especially in the field of Speaking used by the teacher was less innovative. This research uses Research Development with the ADDIE Model which consists of 5 stages, namely: Analysis, Design, Develop, Implement, and Evaluate. The results of this study indicate that learning media based on Sasak language (mother tongue) can help students improve their speaking skills.
\end{abstract}

Keywords: Improvement, Media, Speaking, Sasak

\section{Abstrak}

Berdasarkan studi pendahuluan di SMK Qamarul Huda Bagu kelas X ditemukan berbagai masalah baik dari rendahnya nilai, proses pembelajaran yang kurang interaktif dan media yang digunakan dalam mata pelajaran Bahasa Inggris khususnya pada bidang Speaking/berbicara yang digunakan oleh guru kurang inovatif.metode yang digunakan dalam Penelitian ini menggunakan Research Development dengan Model ADDIE yang terdiri dari 5 tahapan yaitu: Analysis, Design, Develop, Implement, dan Evaluate. Hasil dari penelitian ini menunjukkan bahwa media video pembelajaran berbasis bahasa sasak (bahasa Ibu) dapat membantu siswa dalam meningkatkan kemampuan berbicara.

Kata Kunci: Pengembangan, Media, Speaking, Sasak

\section{PENDAHULUAN}

Berdasarkan studi pendahuluan di SMK Qamarul Huda Bagu kelas X ditemukan berbagai masalah baik dari rendahnya nilai, proses pembelajaran yang kurang interaktif dan media yang digunakan dalam mata pelajaran Bahasa Inggris khususnya pada bidang Speaking/berbicara yang digunakan oleh guru kurang inovatif. Padahal, Media pembelajaran sangat berperan penting dalam menciptakan proses belajar mengajar berjalan aktif, kreatif dan inovatif. Media pembelajaran menjadi faktor penting dalam proses belajar mengajar supaya materi yang disampaikan oleh guru kepada murid dapat diterima dengan baik. Namun, masih banyak ditemukan disekolah swasta yang berlokasi jauh dari perkotaan masih menggunakan media yang kurang interaktif dan proses pembelajaran hanya focus kepada guru. Guru lebih banyak menggunakan media buku dan sumber bacaan lain yang kurang terbaru. media buku dan pola ceramah yang gunakan oleh guru, teruma dalam pembelajara Bahasa Inggris (speaking) yang membutuhkan lebih banyak praktik daripada teori dirasa sulit untuk meningkatkan skill dan prstasi peserta didik. Hal ini bertentangan dengan arah kebijakan Pendidikan di Indonesia untuk menyiapkan sumber daya manusia yang mampu menghadapi dan bersaing terhadap tantangan dimasa depan. Seiring dengan berkembangan teknologi informasi dan komunikasi di zaman ini, guru dituntut untuk dapat menciptakan atau mengembangakan suatu media yang dapat mendukung keberhasilan proses pembelajaran. Dalam mewujudkan sumber daya manusia yang baik, Salah satu cara untuk mencapai itu ialah dengan memamfaatkan seluruh sumber belajar yang ada, termasuk penggunaan media video/ audio visual. Media pembelajaran merupakan sarana penyampaian materi pelajaran yang dapat menyalurkan pesan, merangsang pemikiran dan perasaan serta kemauan seseorang untuk belajar (Haryanto, (2012). Melalui media pembelajaran interaktif memungkinkan peserta didik akan lebih tertarik dan mudah menerima materi yang pelajari. Pemakaian media pembelajaran dalam proses belajar mengajar dapat membangkitkan keinginan dan minat yang baru, membangkitkan motivasi dan rangsangan kegiatan belajar dan bahkan membawa pengaruh-pengaruh psikologi terhadap siswa (Arsyad, (2014).). Di SMK 
Qamarul Huda Bagu, Selama ini guru meyampaikan materi dengan menggunakan media yang konvensional seperti buku, LKS dan sumber monoton lainnya menyebabkan peserta didik krang aktif dalam pembelajaran Speaking. Media video pembelajaran yang berbasis Bahasa Ibu (Bahasa sasak) menjadi salah satu solusi untuk mata pelajaran Speaking. Selain dapat membangkitkan minat beajar, media ini belum pernah dibuat sebelumnya. Media ini nantinya akan memadukan Bahasa daerah asli Lombok (Bahasa sasak) dengan harapan peserta didik dapat belajar Speaking dengan cara yang menyenangkan. Oleh karena itu, media pembelajaran berbasis video berbahasa sasak pada mata pelajaran speaking diharapkan dapat menumbuhkan minat dan kesenangan dalam belajar berbicara Bahasa Inggris.

Penggunaan media pembelajaran yang menarik dan inovatif dapat membantu guru dan siswa dalam belajar mengajar. Media yang baik, selain dapat meningkatkan keaktifan dikelas juga dapat meningkatkan prestasi peserta didik pada satu mata pelajaran tertentu. Kata media berasal dari bahasa latin medius yang secara harfiah berarti "tengah" perantara' atau pengantar. Dalam bahasa arab media adalah perantara atau pengantar pesan dari pengirim kepada penerima pesan. Asocciation For Education And Communication Teknologi (AECT) mendefinisikan media yaitu segala bentuk yang dipergunakan untuk suatu penyaluran informasi. Menurut Education (NEA) mendefinisikan sebagai benda yang dapat dimanipulasikan dilihat, didengar, dibaca atau dibicarakan beserta instrumen yang dipergunakan dengan baik dalam kegiatan belajar mengajar dapat mempengaruhi efektifitas program intruksional.

Video merupakan media yang digunakan untuk menyampaikan pesan pembelajaran. Dalam media video terdapat dua unsur yang saling bersatu yaitu audio dan visual. Adanya unsur audio memungkinkan siswa untuk dapat menerima pesan pembelajaran melalui pendengaran, sedangkan unsur visual memungkinkan penciptakan pesan belajar melalui bentuk visualisasi. Audio visual adalah suatu media yang terdiri dari media visual yang disinkronkan dengan media audio yang sangat memungkinkan terjadinya komunikasi dua arah antara guru dan siswa dalam proses belajar mengajar (Andre,1982). Pendapat lain menyebutkan, media video adalah merupakan rangkaian gambar elektronis yang disertai oleh unsur suara audio juga mempunyai unsur gambar yang dituangkan melalui pita video (video tape). Rangkaian gambar elektronis tersebut kemudian diputar dengan suatu alat yaitu video cassette recorder atau video player (Anderson, Ronald).

Media video pembelajaran yang akan dikembangkan pada penelitian ini berbeda dengan media video pembelajaran yang sudah dikembangkan. Pada penelitian ini penulis ingin mengembangkan sebuah media video pembelajaran berbasis Bahasa Ibu (Bahasa Sasak). Pengembangan media video pembelajaran ini belum pernah dilakukan sebelumnya. Harapannya, media video ini dapat menjadi media yang dapat membantu meningkatkan kemampuan Bahasa Inggris siswa khususnya pada mata pelajaran Speaking.

Ketrampilan berbahasa Indonesia tidak hanya meliputi satu aspek ketrampilan melainkan terdapat empat aspek, yakni aspek kemampuan dalam menulis, kemampuan dalam membaca, kemampuan dalam mendengarkan dan kemampuan dalam berbicaranya (Lamuddin Finoza. 2007).

Media pembelajaran dianggap penting karena berkonstribusi dalam meningkatkan kualitas pembelajaran dan pemahaman siswa. Guru yang bersangkutan juga akan menciptakan strategi dalam mengajarkan inovasi terbaru atau merupakan modifikasi dari strategi yang sudah ada sehingga nantinya akan menghasilkan bentuk baru ( NgainunNaim. 2009).

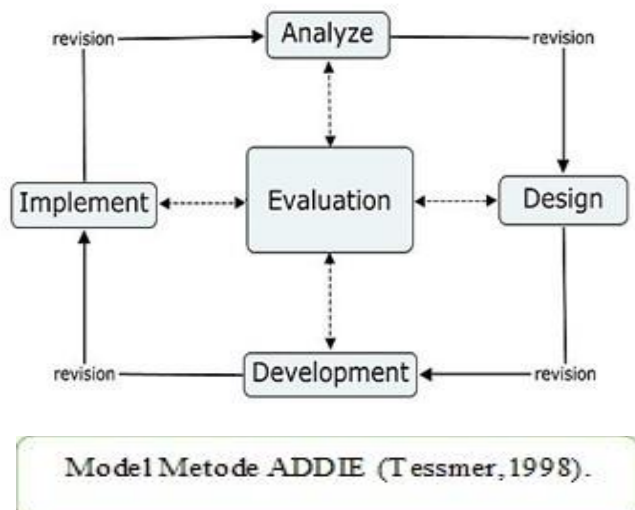

Media pembelajaran memiliki peranan penting dalam menunjang kualitas proses belajar mengajar. Media juga dapat membuat 
pembelajaran lebih menarik dan menyenangkan. Salah satu media pembelajaran yang sedang berkembang saat ini adalah media audiovisual. Dari pengertian di atas dapat disimpulkan bahwa media pembelajaran adalah alat bantudalam proses belajar mengajaruntuk merangsang pikiran, perasaan, perhatian dan kemampuan atau ketrampilan pembelajar sehingga dapat mendorong terjadinya proses belajar (Purwono dkk 2014).

\section{METODE}

Metode yang digunakan dalam penelitian ini ialah Research and development model ADDIE, Analysis, Design, Development, Implement, Evaluation . Hasil Analysis dari Studi pendahuluan di SMK Qamarul Huda Bagu kelas $\mathrm{X}$ ditemukan bahwa media yang digunankan guru dalam mengajar materi Speaking masih konvensional, kurang inovatif dan metode ceramah yang digunakan oleh guru membuat peserta didik susah berkembang. Media buku yang digunakan menyulitkan siswa untuk praktik kemampuan Speaking mereka. untuk menyelesaikan masalah tersebut penulis bermaksud mengembangkan media video pembelajaran Speaking berbasis Bahasa Ibu (Bahasa sasak). Dengan menggunakan Bahasa Sasak sebagai Bahasa Ibu mereka, diharapkan meningkatkan minat dan keaktifan siswa dalam belajar. Selain itu juga media ini nantinya dapat menjadi media pembelajaran yang kreatif inovatif dan menyenangkan.

Tahapan selanjutnya setelah masalah ditemukan ialah Design, pada tahap ini materi dan instrument yang telah disiapkan akan dijadikan media video pembelajaran. Setelah media selesai di buat, tahapan selanjtnya ialah Development Pada tahapan ini, akan di lakukan perincian serta pengintegrasian media yang akan di gunakan untuk mencapai tujuan dari program itu sendiri, kegiatan ini mencakup materi belajar, Adegan dalam video pembelajaran, tahap Development ini meliputi, kegiatan menganalisa, dan memodifikasi sumber belajar dan metode untuk mencapai tujuan dari pembelajaran yang telah ditentukan. Tahapan yang ke empat yaitu Implement, Seluruh media pembelajaran yang sudah dibuat dan dipetakan kemudian diimplementasikan dalam proses belajar mengajar. Tahapan yang terakhir yaitu Evaluation, dalam tahapan ini dilakukan evaluasi dari implementasi media pembelajaran yang telah dilaksankan untuk mengetahui tingkat keberhasilan media yang dikembangkan.

\section{HASIL DAN PEMBAHASAN}

Kemudahan dalam menggunakan media video pembelajaran ini diperoleh dengan penilaian persentase 95,10\%. Hal ini menunjukkan bahwa dengan menggunakan media video pembelajaran ini sangat memudahkan siswa dalam memahami materi dan memudahkan siswa dalam belajar. Dalam media video pembelajaran yang dikembangkan ini jarang ditemukan kata-kata yang sulit dipahami dan mendapatkan penilaian dengan persentase sebesar 91,10\%. Hal ini menunjukkan bahwa kata- kata yang terdapat dalam media video pembelajaran mudah dipahami oleh siswa.

Media video pembelajaran ini membantu siswa untuk dapat menjelaskan materi yang sudah dipahami mendapatkan penilaian dengan persentase sebesar 93,50\%. Hal ini menunjukkan bahwa dengan menggunakan media video pembelajaran ini sangat membantu siswa untuk memahami materi yang diajarkan sehingga siswa dapat menjelaskan kembali materi tersebut dengan lancar.Penggunaan media video pembelajaran ini membantu siswa untuk lebih percaya diri mendapatkan penilaian dengan persentase sebesar $83,90 \%$. Hal ini menunjukkan bahwa dengan menggunakan media video pembelajaran ini membantu siswa untuk lebih paham tentang materi yang diajarkan dan membantu siswa lebih percaya diri untuk menjelaskan kembali materi tersebut didepan kelas.

Berdasarkan penilaian dari angket yang didapat dari uji lapangan diperoleh presentase 91,10\%. Hal ini menunjukkan bahwa media video pembelajaran sangat memudahkan dan menarik bagi siswa dalam belajar. Dengan menggunakan media video pembelajaran siswa dapat memahami pesan pembelajaran secara lebih bermakna dan informasi dapat tersampaikan dan diterima secara utuh sehinnga dengan sendirinya informasi akan tersimpan dalam memory jangka panjang karena didalam media video pembelajaran ini terdapat gambar, 
video media ini sebagai penunjang materi sehingga membuat proses pembelajaran lebih menarik dan menyenangkan.

Berdasarkan hasil analisis perhitungan di atas dapat diperoleh hasil 88,5\%. Angka tersebut jika dikonversikan dengan skala, tingkat kecapaiannya $88,5 \%$ berada pada kualifikasi sangat baik.

\section{KESIMPULAN}

Hasil dari penelitian ini menunjukkan bahwa media video pembelajaran berbasis bahasa sasak (bahasa Ibu) dapat membantu siswa dalam meningkatkan kemampuan berbicara. Selain itu, motivasi siswa dalam belajar juga meningkat, siswa terlihat lebih bersemangat dan aktif dalam proses pembelajaran dikelas. Media video berbasis Bahasa ibu ini juga merupakan media yang unik dan menarik, karena media ini dapat digunakan oleh semua kalangan hal ini menunjukkan bahwa media ini memberikan hasil yang baik dan menjadi sumber pembelajaran bagi guru dan siswa.

\section{SARAN}

Media video pembelajaran ini sangat membantu dalam meningkatkan kemampuan berbicara Bahasa Inggris siswa, sehingga media video sejenis dapat digunakan oleh guru dan dosen sebagai media pembelajaran yang inovatif dan menyenangkan.

\section{UCAPAN TERIMA KASIH}

Terima Kasih Kepada kemendikbud ristekdiki yang telah mendanai penelitian ini, semoga hasil dari penelitian ini dapat memberikan mamfaat dalam mengembangkan mutu pendidikan khusus pada media video pembelajaran. Terima untuk Kepala sekolah SMK Qamarul Huda Badaruddin yang telah memberikan izin penelitian ini, saran, dukungan dan masukan yang diberikan menjadikan penelitian ini dapat selesai sesuai dengan target yang telah ditentukan.

\section{DAFTAR PUSTAKA}

Lamuddin Finoza. 2007. Komposisi Bahasa Indonesia, (Jakarta: Diksi Insan Mulia,), NgainunNaim. 2009. Menjadi Guru Kreatif, (Yogyakarta:PustakaPelajar,), hlm. 142

Haryanto, (2012). Pengertian Media Pembelajaran. (Online) Tersedia: http://belajarpsikologi.com/pengertianmedia-pembelajaran/.

Arsyad, (2014). Media Pembelajaran, Grafindo, Jakarta, ,

Andre, Rinanto (1982). Peranan Media Audio Visual dalam Pendidikan. Yogyakarta: Yayasan Kanisius.

Anderson, Ronald. (1994). Pemilihan dan Pengembangan Media Audio Visual. Jakarta: Grafindo Pers.

Purwono. Joni, dkk. (2014). Penggunaan Media Audio-Visual Pada Mata Pelajaran Ilmu Pengetahuan Alam Di Sekolah Menengah Pertama Negeri1 Pacitan. Dalam Jurnal Teknologi Pendidikan dan Pembelajaran Vol.2, No.2: 127.

Tessmer, M. (1998). Planning and Conducting Formative Evaluations.

Tessmer, M. (1998). Planning and Conducting Formative Evaluations. 